\title{
THE STUDY ON THE CHOICE OF FLAVOURS FOR THE HERBAL SYRUP WITH THE HEPATOTROPIC ACTION
}

\author{
O.O.Shmalko, L.I.Vyshnevska, V.A.Megalinskyi \\ National University of Pharmacy
}

Key words: syrup; excipients; flavour formulations; organoleptic evaluation; composition

\begin{abstract}
Syrups obtained on the basis of the medicinal plant raw material are of special interest for conducting research despite the presence of their specific flavour characteristics, technology of intermediates, and increased susceptibility to microbial contamination. The study concerning substantiation of the choice of the optimal composition of flavours in the syrup based on the original formulation of the medicinal plant raw material (artichoke leaves, wild rose fruits, stevia herb, immortelle flowers, corn silk) has been conducted; the parameters of taste and emotional feelings caused by the drug developed have been studied. Compared to the natural flavour of the syrup, which has a bitter after-taste due to the components of the extracts of artichoke leaves, stevia herb, immortelle flowers, and slightly acid due to wild rose, as well as slightly sweet due to stevia herb, the samples with citric acid (4.90), as well as with the flavour formulation of peach/lemon and cherry/lemon (4.85 and 4.75, respectively) had the highest scores of organoleptic properties. It is interesting to note that compared to the control almost all samples improved emotional feelings. A comparative analysis of the "flavour map" formulations demonstrates that the sample of the syrup with citric acid has the smoothest taste; therefore, citric acid has been chosen for further studies.
\end{abstract}

The specificity of the flavour formation for syrups with the medicinal plant raw material is the availability of their own flavour characteristics due to the presence of extracts with various biologically active substances in the composition: flavonoids and essential oils, which have a bitter taste; polysaccharides and saponins with a peculiar sweet taste; organic acids with a sour taste, and tannins with an astringent taste [1]. It is possible to mask unpleasant sensations and provide acceptable organoleptic properties with flavours improving taste and smell $[2,3]$.

The organoleptic properties of a drug are assessed in complex and are a combination of taste, odour, consistence, etc. It is believed that consumers are more sensitive to odours than tastes, and it is associated with their age group: sensitivity to smells increases 3-5 times in older age; moreover, women are more sensitive to smells than men. Sensations of taste and odour are distorted during various diseases, for example respiratory diseases. Children prefer drugs with a sweet taste, such as vanilla, berries, and fruits. Adults prefer medicines with the taste of chocolate, spices, etc. However, in long-term use a drug with a mild taste or without the taste is the best $[1,7]$. In a number of dosage forms flavours are used; their function is the emotional and gustatory distraction of the patient from the main unpleasant taste or after-taste $[2,8]$.

Currently, flavours are classified into natural ones, those obtained by physical transformations of the raw material of the plant and animal origin (essential oil, fruit juice concentrates etc.) and those that are identical to natural flavours synthesized or extracted from the plant or animal raw material chemically, but they are completely consistent with natural substances (citral, synthetic menthol, vanillin, etc.) $[1,5,7]$.
In recent years new, primarily synthetic, flavours are offered in a number of foreign countries. They find wider application and begin to displace natural flavours because they are cheaper $[6,8]$.

When choosing a flavour introduced to a dosage form it is necessary to consider its incompatibility with drugs, which can lead to various physical and chemical changes of the drug itself and affect its activity.

The aim of the study was to substantiate the choice of the optimal composition of flavours for the syrup based on the original formulation of the medicinal plant raw material.

\section{Materials and Methods}

The parameters of taste and emotional feelings caused by the syrup obtained on the basis of the aqueous plant extract from artichoke leaves, wild rose fruits, stevia herb, immortelle flowers, and corn silk were studied.

The classic approach according to the methods of the "flavour panel" by A.V.Tentsova and the "flavour map" by I.A. Yegorov was used $[3,4]$.

The organoleptic method for evaluation of flavours proposed by A.V.Tentsova is based on distribution of perception intensity of sensations and emotions when conducting the analysis. The organoleptic evaluation of the flavours studied was performed in the group of 20 persons according to the five-point grading scale. From the data obtained the taste index was deduced as the arithmetic mean from the evidence of all persons involved in testing. The higher was the masking potential of a flavour, the greater was the numerical index.

To determine the flavour profile of the samples of the syrup under research such essences as chocolate, lemon, coffee, peach, raspberry, cherry and their combinations - chocolate/coffee, lemon/mint, raspberry/lemon, cherry/lemon, peach/lemon, citric acid were selected. 
Table 1

Table 2

The composition panel of the model samples of the syrup with flavours

\begin{tabular}{|l|c|c|}
\hline \multicolumn{1}{|c|}{ Formulation } & $\begin{array}{c}\text { Assessment of } \\
\text { the basic taste }\end{array}$ & $\begin{array}{c}\text { Assessment } \\
\text { of the taste } \\
\text { of emotional } \\
\text { feelings }\end{array}$ \\
\hline Control & \pm 0.12 & \pm 0.11 \\
\hline Chocolate/chocolate & $4.05 \pm 0.10$ & $3.10 \pm 0.13$ \\
\hline Coffee/coffee & $4.10 \pm 0.12$ & $3.05 \pm 0.11$ \\
\hline Coffee/chocolate & $4.15 \pm 0.11$ & $3.15 \pm 0.12$ \\
\hline Lemon/lemon & $3.90 \pm 0.12$ & $2.90 \pm 0.12$ \\
\hline Lemon/mint & $3.80 \pm 0.13$ & $3.40 \pm 0.16$ \\
\hline Peach/peach & $4.40 \pm 0.13$ & $4.00 \pm 0.11$ \\
\hline Peach/lemon & $4.75 \pm 0.14$ & $4.10 \pm 0.14$ \\
\hline Raspberry/raspberry & $4.10 \pm 0.12$ & $3.20 \pm 0.15$ \\
\hline Cherry/cherry & $4.35 \pm 0.14$ & $3.50 \pm 0.14$ \\
\hline Raspberry/lemon & $4.30 \pm 0.10$ & $3.60 \pm 0.12$ \\
\hline Raspberry/cherry & $4.05 \pm 0.13$ & $3.05 \pm 0.10$ \\
\hline Cherry/lemon & $4.85 \pm 0.15$ & $4.20 \pm 0.11$ \\
\hline Citric acid & $4.90 \pm 0.12$ & $4.65 \pm 0.13$ \\
\hline
\end{tabular}

\section{Results and Discussion}

The results of the study are given in Tab. 1.

Analyzing the data from Tab. 1 it can be concluded that compared to the natural flavour of the syrup, which has a bitter after-taste due to the components of the extracts of artichoke leaves, stevia herb, immortelle flowers, and slightly acid due to wild rose, as well as slightly sweet due to stevia herb, the samples with citric acid (4.90), as well as with the flavour formulation of peach/ lemon and cherry/lemon (4.85 and 4.75, respectively) had the highest scores of organoleptic properties. It should be noted that compared to the control almost all samples improved emotional feelings.

The comparative analysis of the "flavour map" formulations is presented in Tab. 2 .

The comparative analysis of the "flavour map" formulations (Tab. 2) shows that they corrected the available after-tastes of bitterness of the extract of artichoke leaves and immortelle flowers, as well as the acid taste of wild rose not fully. The sample of the syrup with citric acid had the smoothest taste.

Therefore, as a result of the studies conducted according to the methods of the "flavour panel" and the
The flavour map of the samples of the syrup studied

\begin{tabular}{|c|c|c|}
\hline Formulation & \begin{tabular}{|c|}
$\begin{array}{c}\text { The } \\
\text { formula of } \\
\text { taste }\end{array}$ \\
\end{tabular} & The general taste \\
\hline Control & ГЗК2О2 & $\begin{array}{l}\text { Bitter, slightly acid, } \\
\text { slightly sweet }\end{array}$ \\
\hline Chocolate/chocolate & 「2O2 & $\begin{array}{l}\text { Slightly bitter, } \\
\text { slightly sweet }\end{array}$ \\
\hline Coffee/coffee & Г2O2 & $\begin{array}{l}\text { Slightly bitter, } \\
\text { slightly sweet }\end{array}$ \\
\hline Coffee/chocolate & Г2O2 & $\begin{array}{l}\text { Slightly bitter, } \\
\text { slightly sweet }\end{array}$ \\
\hline Lemon/lemon & Г2O2 & $\begin{array}{l}\text { Slightly bitter, } \\
\text { slightly sweet }\end{array}$ \\
\hline Lemon/mint & Г2К2О2 & $\begin{array}{c}\text { Slightly bitter, } \\
\text { slightly acid sweet }\end{array}$ \\
\hline Peach/peach & 「2O2 & $\begin{array}{l}\text { Slightly bitter, } \\
\text { slightly sweet }\end{array}$ \\
\hline Peach/lemon & Г2К2O2 & $\begin{array}{c}\text { Slightly bitter, } \\
\text { slightly acid sweet }\end{array}$ \\
\hline Raspberry/raspberry & $\lceil 2 \mathrm{O} 2$ & $\begin{array}{l}\text { Slightly bitter, } \\
\text { slightly sweet }\end{array}$ \\
\hline Cherry/cherry & $\Gamma 2 \mathrm{O} 2$ & $\begin{array}{l}\text { Slightly bitter, } \\
\text { slightly sweet }\end{array}$ \\
\hline Raspberry/lemon & Г2К2O2 & $\begin{array}{c}\text { Slightly bitter, } \\
\text { slightly acid sweet }\end{array}$ \\
\hline Raspberry/cherry & $\lceil 2 \mathrm{O} 2$ & $\begin{array}{l}\text { Slightly bitter, } \\
\text { slightly sweet }\end{array}$ \\
\hline Cherry/lemon & $\mathrm{O} 2 \Gamma 2$ & $\begin{array}{l}\text { Slightly sweet, } \\
\text { slightly bitter }\end{array}$ \\
\hline Citric acid & $\mathrm{O} 2$ & Slightly sweet \\
\hline
\end{tabular}

"flavour map" the flavour profile of the syrup with artichoke leaves, wild rose fruits, stevia herb, immortelle flowers, and corn silk was determined. Citric acid in the concentration of $0.4 \%$ was chosen as the optimal flavour.

CONCLUSIONS

As a result of the study of the masking potential of a number of flavour formulations according to the methods of the "flavour panel" and the "flavour map" the dicinal plant raw material has been determined. Citric acid in the concentration of $0.4 \%$ has been chosen as the optimal flavour. flavour profile of the combined syrup based on the me-

\section{REFERENCES}

1. Довженок И.А. // Провизор. - 2008. - №5. - C. 17-19.

2. Краснокурский П.С. // Новая аптека. - 1998. - №1. - С. 16-17.

3. Маравина С.В. // Фармащия. - 2001. - №5. - C. 31.

4. Тенцова А.И. Получение и исследование лекарственных форм для детей: Автореф. дис. ... д-ра фарм. наук. - Тбилиси, 1971. - 27 с.

5. Шмалько А.А., Вишневская Л.И., Мегалинский В.А. // Вестник ЮКГФА. - 2015. - №4 (73). - С. 116-119.

6. Barbeskar C., Geeverghese R. // World J. Pharmac. Res. - 2015. - №4. - P. 462-484.

7. Kaushik A., Chauhan V. // Eur. J. of Pharmac. and Med. Res. - 2016. - №3 (5). - P. 517-522.

8. Shmalko O., Vyshnevska L., Strilets O., Iakovenko V. // Sci.Rise. - 2016. - №2 (2). - P. 4-10. 


\section{ДОСЛІДЖЕННЯ 3 ВИБОРУ КОРИГЕНТІВ СМАКУ ФІТОСИРОПУ ГЕПАТОТРОПНОЇ ДІЇ О.О.Шмалько, Л.І.Вишневська, В.А.Мегалінський}

Ключові слова: сироп; допоміжні речовини; коригувальні композиції; органолептичне оцінювання; склад

Сиропи, отримані на основі лікарської рослинної сировини (ЛРС), становлять особливий інтерес для проведення досліджень, зважаючи на наявність власних специфічних смакових характеристик, технологію напівпродуктів, підвищену вразливість до мікробної контамінації. Нами проведене дослідження з обгрунтування вибору оптимального складу коригентів смаку сиропу на основі оригінальної композиції лікарської рослинної сировини (листя артишоку, плодів шипшини, трави стевії, квіток цмину, стовпчиків з приймочками кукурудзи) та вивчені параметри смаку і емоційних почуттів, які викликає розроблений лікарський засіб. У порівнянні з природним смаком сиропу, який має гіркий присмак через складові екстрактів листя артишоку, трави стевії та квіток имину і слабокислий завдяки шипшині, а також слабосолодкий завдяки траві стевії, найвищі бали органолептичних властивостей мали зразки з кислотою лимонною $(4,90)$, а також композицією коригентів персик/лимон та вишня/лимон (4,85 і 4,75 відповідно). Варто зазначити, що у порівнянні з контролем емоційне відчуття поліпшували практично усі дослідні зразки. Порівняльний аналіз композицій «смакової карти» показує, що найбільш комфрортним смаком володіє дослідний зразок сиропу з кислотою лимонною, яку і було обрано для подальших досліджень.

\section{ИССЛЕДОВАНИЯ ПО ВЫБОРУ КОРРИГЕНТОВ ВКУСА ФИТОСИРОПА ГЕПАТОТРОПНОГО ДЕЙСТВИЯ}

А.А.Шмалько, Л.И.Вишневская, В.А.Мегалинский

Ключевые слова: сироп; вспомогательные вещества; корригирующие композиции; органолептическое оценивание; состав

Сиропы, полученные на основе лекарственного растительного сырья (ЛРС), представляют особый интерес для проведения исследований, учитывая наличие собственных специфрических вкусовых характеристик, технологию полупродуктов, повышенную восприимчивость к микробной контаминации. Нами проведены исследования по обоснованию выбора оптимального состава корригентов вкуса сиропа на основе оригинальной композиции лекарственного растительного сырья (листьев артишока, плодов шиповника, травы стевии, цветков бессмертника, кукурузных рылец) и изучены параметры вкуса и эмоциональных чувств, которые вызывает разработанное лекарственное средство. В сравнении с природным вкусом сиропа, который имеет горький привкус из-за составляющих экстрактов листьев артишока, травы стевии и иветков бессмертника и слабокислый благодаря шиповнику, а также слабосладкий благодаря траве стевии, самые высокие баллы органолептических свойств имели образцы с кислотой лимонной $(4,90)$, а также композицией корригентов персик/лимон и вишня/лимон (4,85 и 4,75 соответственно). Следует подчеркнуть, что в сравнении с контролем эмоциональное чувство улучшали практически все опытные образцы. Сравнительный анализ композиций «вкусовой карты» показывает, что наиболее комфортным вкусом обладает опытный образец сиропа с кислотой лимонной, который и был выбран для дальнейших исследований. 